\title{
PERFORMANCE OF TUBULAR STRUCTURE UNDER SEISMIC FORCE
}

\section{DIWAKAR CHAUDHARY \& GURPREET SINGH}

Research Scholar, Department of Civil Engineering, Chandīgarh University, Mohali, Punjab, India

Assistant professor, Department of Civil Engineering, Chandigarh University, Mohali, Punjab, India

\begin{abstract}
Advancement in the building construction technology and structural analysis the tall structures have been significantly increased due to over growing population and for land mark of country. The tall structures are more prone to lateral load. In this study different forms of tubular structure are used to resist the Earthquake forces. Tubular structures are made based on the idea that building is design to act like a hollow cylinder cantilever perpendicular to the grounds. The aim of this paper is to present the seismic performance of tubular structure with and without central core. The Framed tube system, Tube in tube system, Bundled tube system, Braced tube system and Moment resisting Frame was analyzed to draw the comparison on the basis of storey drift, time period and storey shear satisfying the structural codes- IS 456-2000, IS 1893(Part 1):2016 in E-TABs software by Response spectrum method.

KEYWORDS: Framed Tube System, Tube in Tube System, Bundled Tube System, Braced Tube System Storey Displacement, Storey Drift, Time Period and Storey Shear, Response Spectrum Method, E-Tabs
\end{abstract}

Received: Jun 08, 2020; Accepted: Jun 28, 2020; Published: Aug 21, 2020; Paper Id.: IJMPERDJUN2020854

\section{INTRODUCTION}

Tall structures are constructed rapidly due to advancement in the building construction technology and structural analysis due to overgrowing population, urbanization and to make the land marks of the country the structure are made to be taller. The structures are said to be tall, if it is higher than low - rise structure. The taller structure is more prone to earthquakes forces. For the stability of the structure to with stand the lateral forces the different structural forms has been designed over the last decades. The construction of tall structure is possible with tubular structure forms by the concepts the structure is design to act like a hollow cylinder cantilever perpendicular to the grounds. The concept of tubular system was developed by Dr. Fazlur Khan. Tubular system is economic, safe and serviceable for tall structure than conventional framed system in high- rise structure. Tubular structure can be constructed using steel, concrete and composite construction. In the tubular system closely spaced column is connected with deep spandrel beams that are tied together form a rigid frame that amount to dense and strong structural wall along the exterior of the building. The exterior framing is designed sufficiently strong to resist all lateral loads on the building, thereby allowing the interior

\section{TYPES OF TUBULAR SYSTEM}

\section{- $\quad$ Framed Tube System}

It is modification in the moment resisting frame where the exterior shell is made by closely spaced column of 1.5 4.5 , which is connected by deep spandrel beam of $0.5-1.5$ in the structure. In this system, the exterior shell is design to resist lateral load and interior beam and column is design to resist gravity load. 
- Tube in Tube System

This structural system is advancement in the framed tube system in which outer tube around the exterior and the inner tube is formed at the inner core. The tubes are interconnected by the floor slab and works together to resist the lateral loads to provide stability and rigidity in the structure.

\section{- Bundled Tube System}

The Bundled tube system consist of multi cellular tube interconnected with each other and they work together to resist lateral loads and overturning moment experienced by the structure. This system is economically efficient and versatile structure can be build.

\section{- Braced Tube System}

Frame tube system consists of additional bracing system in its exterior farming than it is said to be braced tube system. The interconnection of all the exterior columns forms rigid box to withstand lateral forces. In this system it is possible to have a lot of space for window due to abroad spacing of column.

\section{OBJECTIVES OF THE STUDY}

- To prepare the models of various forms of 40 storey tall tubular structure with and without core in E-TABS software

- $\quad$ To analyze the modeled buildings according to IS code 1893(part-1):2016.

- To know the seismic behavior of analyzed tubular structures.

- $\quad$ To determine parameter such as story displacement, story drift, storey shear and time period.

- To compare the results of tubular structure with and without core on the basis of seismic parameters such as story drift, story displacement, storey shears and time period in the reference of moment resisting frame.

- To find out the most effective lateral load resisting system among tubular structure

\section{MODELING AND ANALYSIS}

In present research work, 40 storied reinforced concrete structures with constant floor height of 3 meter and dimension of plan is $40 \mathrm{~m}$ x $40 \mathrm{~m}$ is considered. All together 9 models has used for the study. Different forms of tubular structures with and without core had been modeled taking base model as moment resisting frame. The core is placed at the centre and it is about $6.25 \%$ of total area space. The dimension of core is $10 \mathrm{~m} \times 10 \mathrm{~m}$. The spacing of column in the case of tubular structure is $2.5 \mathrm{~m}$ centre to centre to form a tube where as in moment resisting frame is $5 \mathrm{~m}$ Centre to Centre. The structures are located in zone 4, so the dynamic analysis according to IS 1893(part1): 2016 had been conducted. Modeling and analysis was done in ETABs 2017 software. The preliminary data required for the analysis of building are tabulated below.

Table 1: Preliminary Data for Buildings

\begin{tabular}{|c|l|c|}
\hline S. No & \multicolumn{1}{|c|}{ Particulars } & Dimension/Size/Value \\
\hline 1 & Plan dimension & $40 \mathrm{~m} \mathrm{x} \mathrm{40m}$ \\
\hline 2 & No. of stories & 40 \\
\hline 3 & Height of the floor & $3 \mathrm{~m}$ \\
\hline 4 & No. of grids in X dir. & 9 \\
\hline 5 & No. of grids in Y dir. & 9 \\
\hline
\end{tabular}




\begin{tabular}{|c|l|c|}
\hline 6 & Spacing of grids in X dir. & 5 \\
\hline 7 & Spacing of grids in Y dir. & 5 \\
\hline 8 & Size of column (1 to 10 storey) & $800 \mathrm{~mm} \times 800 \mathrm{~mm}$ \\
\hline 9 & Size of column (11 to 20 storey) & $700 \mathrm{~mm} \times 700 \mathrm{~mm}$ \\
\hline 10 & Size of column (21 to 30 storey) & $600 \mathrm{~mm} \times 600 \mathrm{~mm}$ \\
\hline 11 & Size of column (31 to 40 storey) & $500 \mathrm{~mm} \times 500 \mathrm{~mm}$ \\
\hline 12 & Bay length of tube & $2.5 \mathrm{~m}$ \\
\hline 13 & Primary beam & $300 \mathrm{~mm} \mathrm{\times} \mathrm{600mm}$ \\
\hline 14 & Secondary beam & $300 \mathrm{~mm} \mathrm{\times} \mathrm{500mm}$ \\
\hline 15 & Thickness of core wall & $250 \mathrm{~mm}$ \\
\hline 16 & Thickness of slab & $150 \mathrm{~mm}$ \\
\hline 17 & Grade of concrete & $\mathrm{M} 30$ \\
\hline 18 & Grade of rebar & $4 \mathrm{kN} / \mathrm{m}^{2}$ \\
\hline 19 & Live loads & $1 \mathrm{kN} / \mathrm{m}^{2}$ \\
\hline 20 & Floor loads & iv \\
\hline 21 & Seismic zone & 2 \\
\hline 22 & Type of soil & 0.24 \\
\hline 23 & Zone factor & 5 \\
\hline 24 & Response reduction(R) & $10 \mathrm{~m} \mathrm{x10m}$ \\
\hline 25 & Important factor & \\
\hline 26 & Core dimension & \\
\hline & & \\
\hline
\end{tabular}

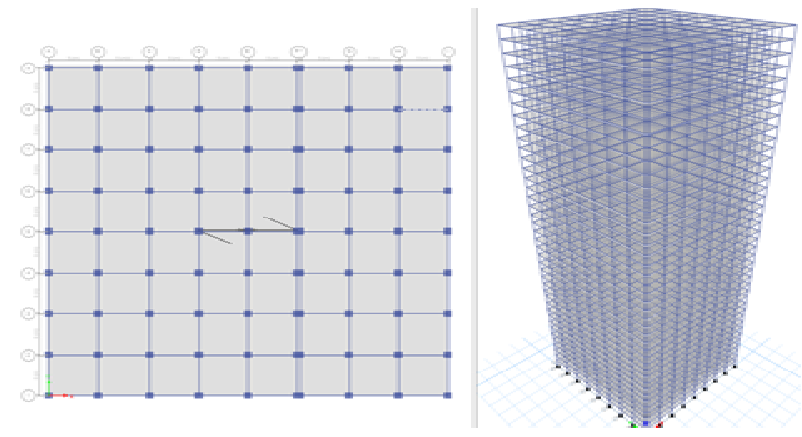

Figure 1: Plan \& 3D View of Moment Resisting Frame Model.
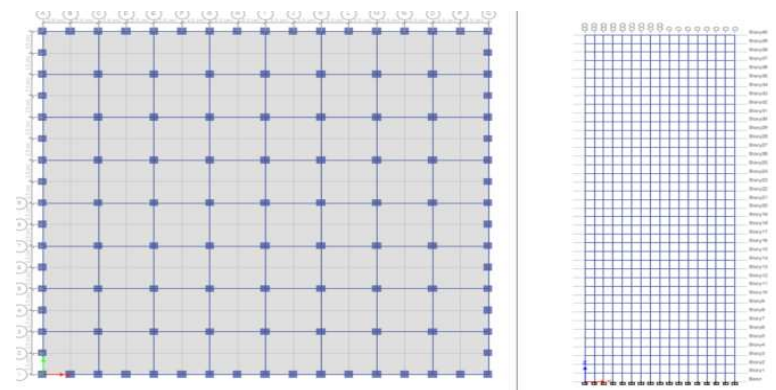

Figure 2: Plan \& Elevation of Frame Tube Model.

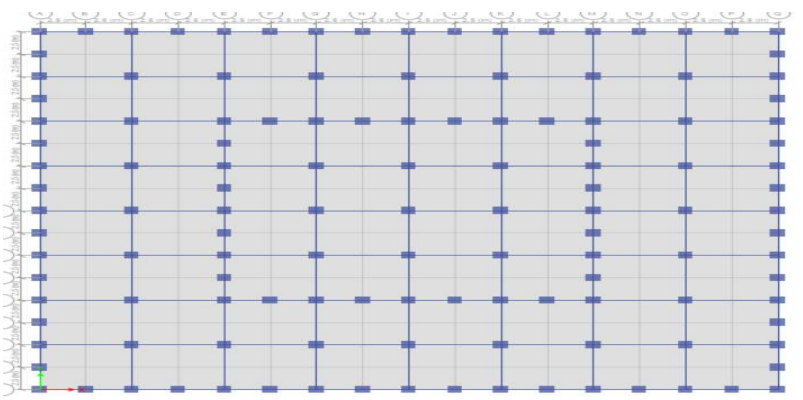

Figure 3: Plan of Tube in Tube Model. 


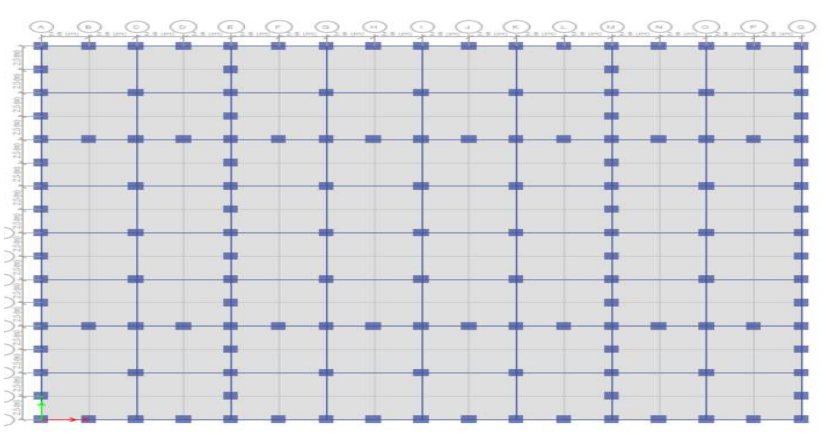

Figure 4: Plan of Bundled Tube Model.
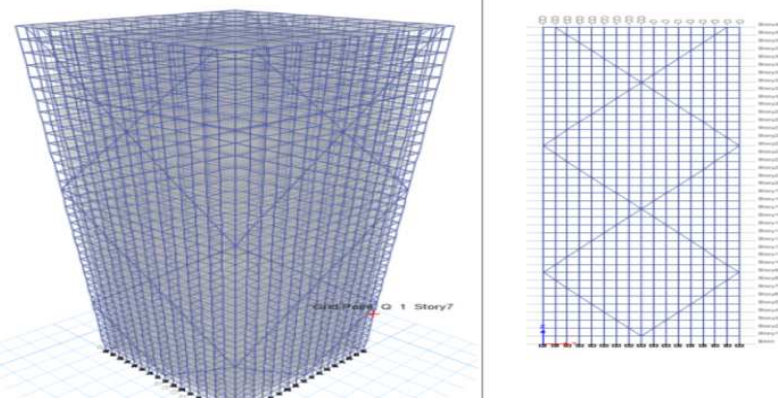

Figure 5: 3D View \& Elevation of Braced tube model

\section{RESULTS AND DISCUSSIONS}

Response spectrum method is applied on the model to perform seismic analysis as per IS 1893(part1):2016 in zone 4. The effect of core in the tubular structure is evaluated based on the seismic parameter such as Storey displacement, storey shear and time period. All the results has been observed and tabulated below.

\section{- Storey Displacement}

It is the maximum horizontal displacement of storey with respect to its base. In the case of high rise structure the displacement is important parameter for the stability of structure against lateral load. According to high rise building code the lateral displacement shouldn't exceed H/500, where $\mathrm{H}$ is the total height of building. All the models are within permissible displacement. The storey displacement of different model in $\mathrm{X}$ and $\mathrm{Y}$ direction is as follows:

From the graph and table, it can be observed that as height of building increase, the storey displacement is increased. Moment resisting frame has larger displacement in compare to tubular structure. The displacement of framed tube system, tube in tube system, bundled tube system and braced tube system is reduced to $28.5 \%, 32.5 \%, 35 \%, 40.22 \%$ in X-direction and $29.5 \%, 33.17 \%, 35.91 \%, 41 \%$ in Y-direction respectively in compare to moment resisting frame where as in addition with core in frame tube system, tube in tube system, bundled tube system and braced tube system is reduced to $36.40 \%, 39.44 \%, 41.82 \%, 45.37 \%$ in X-direction and 37.04, $39 \%, 42.46,45$ in Y - direction.

Table 2: Result of Maximum Displacement

\begin{tabular}{|c|l|c|c|}
\hline \multirow{2}{*}{ S. No } & \multicolumn{2}{|c|}{ Structural System } & \multicolumn{2}{c|}{ Displacement( in Mm) } \\
\cline { 3 - 4 } & & X-Direction & Y-Direction \\
\hline 1 & Moment resisting frame & 134.295 & 135.646 \\
\hline 2 & Framed tube system & 95.825 & 95.825 \\
\hline 3 & Tube in tube system & 90.641 & 90.641 \\
\hline 4 & Bundled tube system & 86.942 & 86.929 \\
\hline 5 & Braced tube system & 80.016 & 80.016 \\
\hline
\end{tabular}




\begin{tabular}{|c|l|c|c|}
\hline 6 & Framed tube system with Central core & 85.401 & 85.401 \\
\hline 7 & Tube in tube system with Central core & 81.329 & 81.52 \\
\hline 8 & Bundled tube system with Central core & 78.128 & 78.041 \\
\hline 9 & Braced tube system with Central core & 73.362 & 73.447 \\
\hline
\end{tabular}

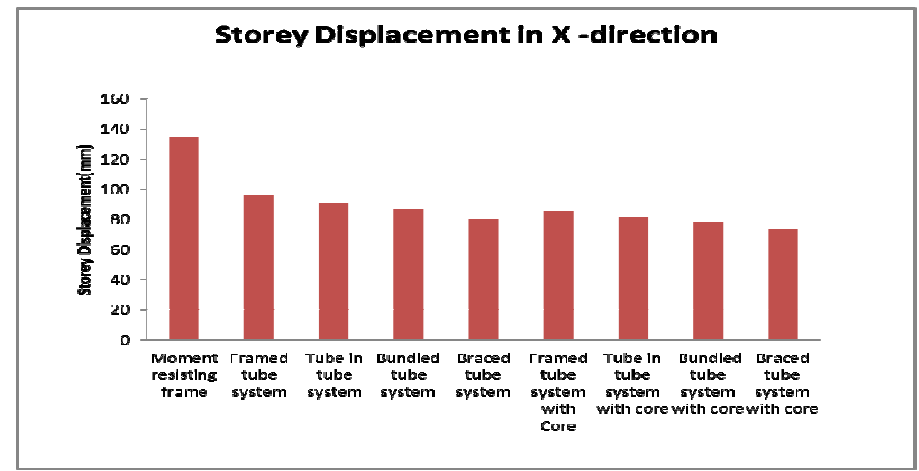

Figure 6: Comparison of Displacement in X-Direction.

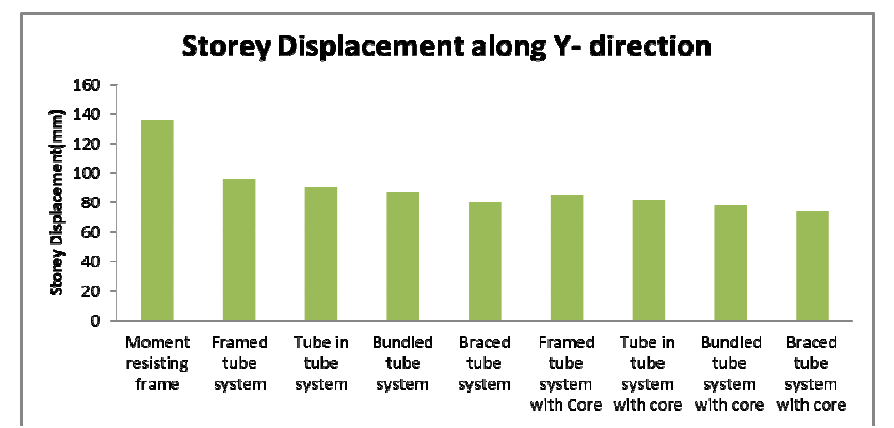

Figure 7: Comparison of Displacement in Y-Direction.

\section{- Storey Drift}

Story drifts is the difference in displacement of two successive stories divided by the height of that floor. The maximum storey drift in any storey of building due to lateral loads should not exceed $0.4 \%$ of storey height as per IS 875:2016(part3). In present work all the model are within permissible value. The storey drift of different model in $\mathrm{X}$ and $\mathrm{Y}$ direction is as follows:

From below graph, it was observed that the moment resisting frame have greater storey drift than tubular structure. The storey drift is significantly decreased with the tubular structure. The entire models have the maximum storey drift at 21 storeys. The storey drift is reduced to $18 \%, 22 \%, 31.1 \%$, and $26 \%$ in frame tube system, tube in tube system, bundled tube system, and braced tube system in compare to moment resisting frame. In addition of core in frame tube system, tube in tube system, bundled tube system and braced tube system the storey drift is decreased to $33.33 \%, 36.6 \%$, $39.08 \%$ and $41 \%$ in compare to moment resisting frame.

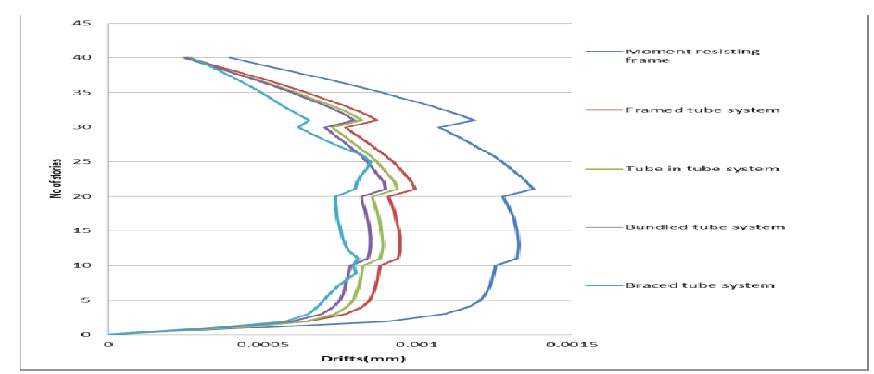

Figure 8: Comparison of Storey Drifts along X-Direction. 


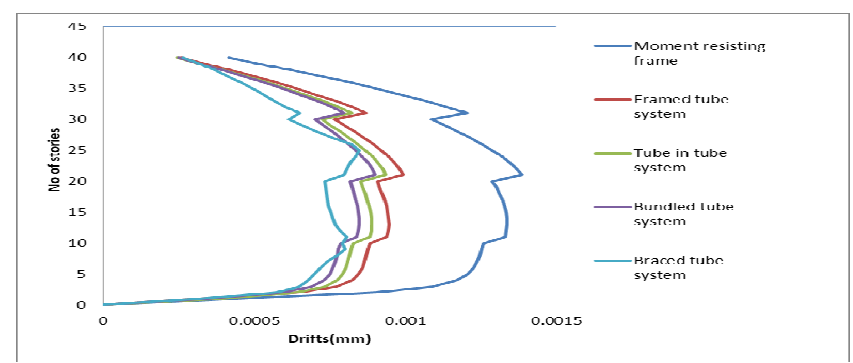

Figure 9: Comparison of Storey Drifts along X-Direction.

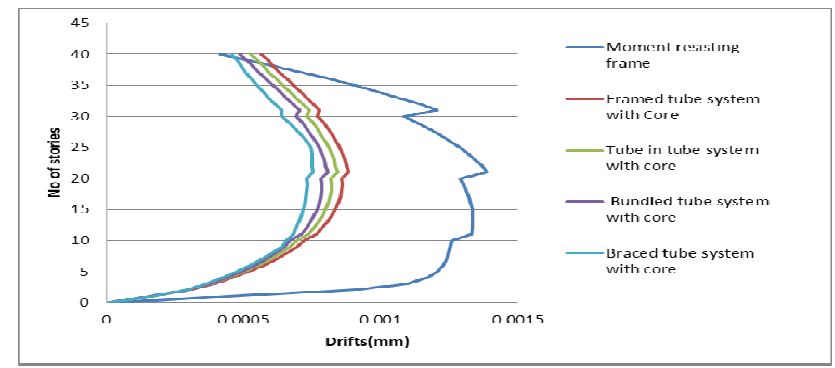

Figure 10: Comparison of Storey Drifts along Y-Direction.

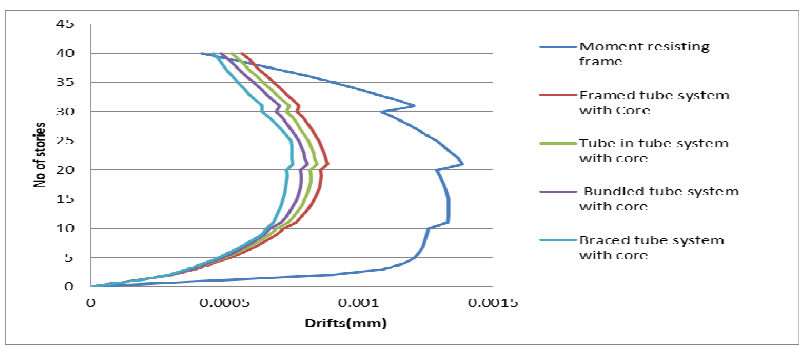

Figure 11: Comparison of Storey Drifts along Y-Direction.

\section{- Storey Shear}

The design lateral load acting on each floor level is called storey shear. The values of storey shear are maximum at the bottom and minimum at the top. The comparative maximum values of storey shear in $\mathrm{X}$ and $\mathrm{Y}$ direction is tabulated and presented in the bar graph below:

From bar graph, it is observed the storey shear increase in tubular structure in compare to moment resisting frame. It is increased to $10.01 \%, 19.31 \%, 28.69 \%, 30.65 \%$ in framed tube system, tube in tube system, bundled tube system, braced tube system without core and with core it is increased to $37 \%, 46.08 \%, 54.40 \%, 52.55 \%$ respectively

Table 3: Result of Storey Shear (in kN)

\begin{tabular}{|c|l|c|c|}
\hline \multirow{2}{*}{ S. No } & \multicolumn{1}{|c|}{ Structural System } & \multicolumn{2}{c|}{ Story Shear( In KN) } \\
\cline { 3 - 4 } & & X-Direction & Y-Direction \\
\hline 1 & Moment resisting frame & 8654.9218 & 8644.2981 \\
\hline 2 & Framed tube system & 9536.4519 & 9529.9187 \\
\hline 3 & Tube in tube system & 10326.2225 & 10321.1374 \\
\hline 4 & Bundled tube system & 11112.3598 & 11116.24 \\
\hline 5 & Braced tube system & 11308.2549 & 11306.0773 \\
\hline 6 & Framed tube system with Central core & 11918.0633 & 11915.7684 \\
\hline 7 & Tube in tube system with Central core & 12638.6567 & 12636.9077 \\
\hline 8 & Bundled tube system with Central core & 13363.3092 & 13360.639 \\
\hline 9 & Braced tube system with Central core & 13203.9352 & 13199.4472 \\
\hline
\end{tabular}




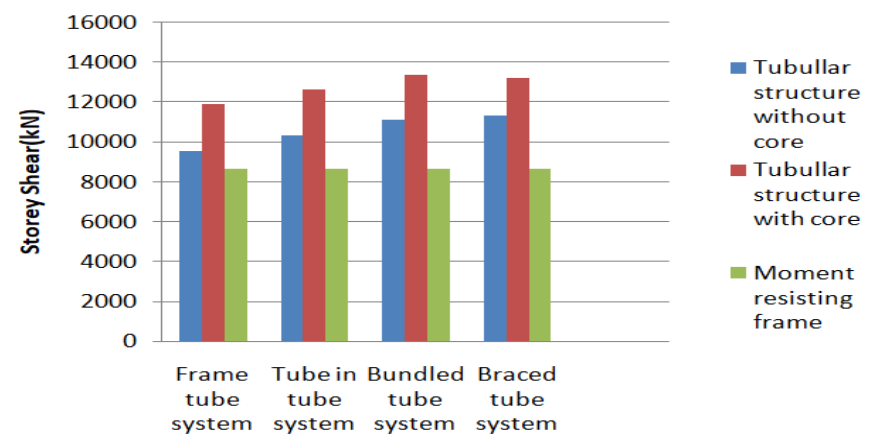

Figure 12: Comparison of Storey Shear along X-Direction.

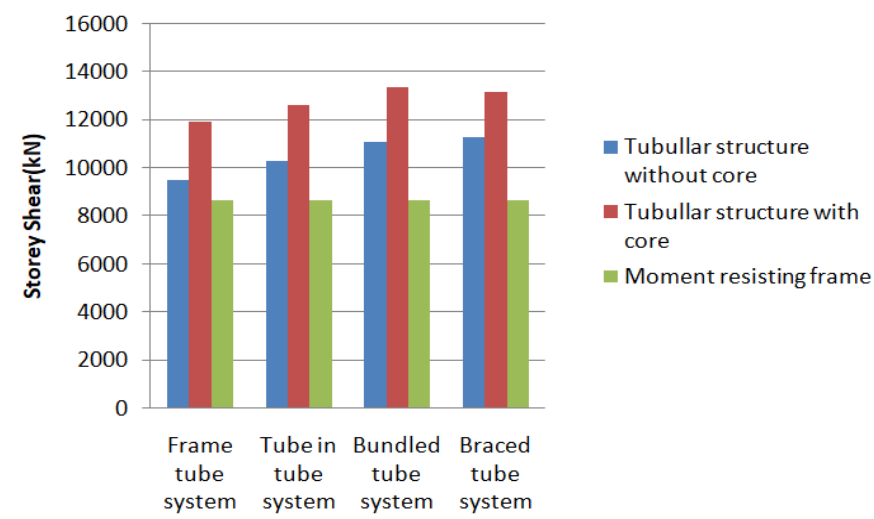

Figure 13: Comparison of Storey Shear along Y-Direction.

\section{- $\quad$ Time Period}

The time required to complete one oscillation of structure during earthquake is called time period. The time period of the entire model are tabulated and presented in graph as follows:

From below graph, it is observed that moment resisting frame have maximum time period than tubular structure. The time period is reduced to $18 \%, 22.8 \%, 26 \%$, and $31.19 \%$ in the frame tube system, tube in tube system, bundled tube system and braced tube system respectively in comparison to moment resisting frame. In addition to central core in the frame tube system, tube in tube system, bundled tube system and braced tube system the time period is decreased to $33.33 \%, 36.6 \%, 39.08 \%$ and $41 \%$ respectively. The reduction in time period makes the structure stable during earthquake motion

Table 4: Time Period (in Sec)

\begin{tabular}{|c|l|c|}
\hline S. No & \multicolumn{1}{|c|}{ Structural System } & Time Periods( in Sec) \\
\hline 1 & Moment resisting frame & 4.59 \\
\hline 2 & Framed tube system & 3.756 \\
\hline 3 & Tube in tube system & 3.539 \\
\hline 4 & Bundled tube system & 3.354 \\
\hline 5 & Braced tube system & 3.158 \\
\hline 6 & Framed tube system with Central core & 3.058 \\
\hline 7 & Tube in tube system with Central core & 2.91 \\
\hline 8 & Bundled tube system with Central core & 2.796 \\
\hline 9 & Braced tube system with Central core & 2.672 \\
\hline
\end{tabular}




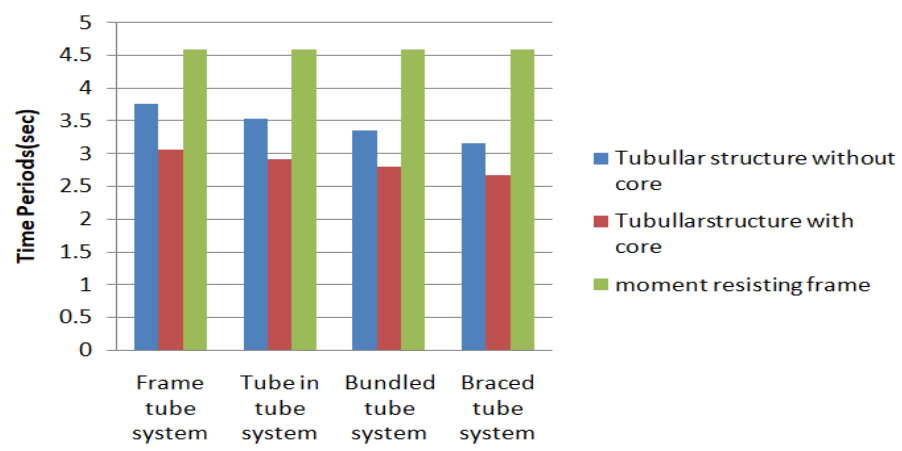

Figure 14: Comparison of Time period.

\section{CONCLUSIONS}

\section{From Above Results and Discussion the Conclusion Have Been Drawn As Follows:}

- $\quad$ The displacement value of all the tubular structure system shows the reduced displacement in both $\mathrm{X}$ and Y direction as comparing with moment resisting system. However the frame tube system shows the highest and braced tube system shows least displacement in compare to all the tubular system.

- Storey drift of the entire all the structural system have low values of storey drift at the ground and maximum values at the middle of the structures. Moment resisting frame show more values of storey drift in compare to other structural system.

- $\quad$ Storey shear of all the tubular structure is greater than moment resisting frame.The results shows that tubular structure with core has increased in storey shear than tubular structure without core.

- $\quad$ Frame tube system and braced tube system has highest and least time period in compare to other tubular structures. It shows that addition of core at the centre of tubular structures decreased the time period more as compared to tubular structure without core.

Finally, we concluded that the tubular structures are very economical and better lateral load resisting system than moment resisting frame system. In addition of core in the tubular structure makes the structure more efficient and stable in resisting the earthquakes forces. It is seen that braced tube system with and without core had better performance to resist the lateral in comparison to other tubular structure.

\section{REFERENCES}

1. Ghasemi, “EVALUATION OF SEISMIC BEHAVIOUR OF IRREGULAR TUBE BUILDINGS IN TUBE SYSTEMS”, Advance in Science and Technology Research Journal, Vol. 10,2016, pp. 4651.

2. Eadukondalu and Reddy, "Study of Lateral Structural Systems in Tall Buildings", International Journal of Applied Engineering Research, Vol.13, 2018, pp.1173811754.

3. Lu Xinzheng, XieLinlin, Yu Cheng and Lu Xiao, "Development and application of a simplified model for the design of a supertall mega tall- braced frame - core tube building”, ELSEVIER,Vol.110 2016, pp. 116126.

4. Patel and John, "Seismic analysis of frame tube structure", International journal of Scientific \& Engineering Research, Vol.6, Issue12, 2015, pp.22295518.

5. Brunesi,Nascimbene, Casagrande, “Seismic analysis of High-rise Mega-braced framer-core building”, ELSEVIER, Vol. 115, 2016 pp.117. 
6. Thapa, Axay, and Sajal Sarkar. "Comparative Study of Multi-Storied RCC Building with and without Shear Wall." International Journal of Civil Engineering (IJCE) Vol 6.

7. Wadagule and Charantimath, "Comparative study of tube in tube structure and Frame tube structure", International Research journal of Engineering and Technology, Vol.6, Issue 7,july-2019,pp.16681673.

8. Zhang, Lu, Z. Lu, Ye and Qian, “Collapse for a Super-Tall Mega - braced frame Core- tube building”, 15th World Conference on Earthquake Engineering 2012.

9. L. Shruthi and Vijaya S., "seismic Analysis of Lattice Shell Tube RC Framed Building," International Journal of Engineering Research and Technology, Vol. 3, Issue 7, 2014, pp. 12011205.

10. AWCHAT, GD, and YAMINI N. DESHMUKH. "SEISMIC RESPONSE OF TALL BUILDING WITH UNDERGROUND STOREY USING DAMPERS. "International Journal of Civil Engineering (IJCE) 6. 4, Jun- Jul 2017; 5766.

11. Essam., Ayyash and Ghoniem E.H, "Seismic Response of High- Rise Buildings with Different Structural System", International journal of Engineering and Innovative Technology, Vol. 8, Issue 9, November -2018,pp.4251.

12. Mantha, Vinay, and Sanghai SS. "Comparison between Seismic Analysis and Non-Seismic Analysis of G+ 17 Building Using Sap2000." International Journal of Earthquake Engineering and Geological Science,(IJEEGS) 6.2 (2016).

13. Tuna, Wallace, Yang and Moehl, " Seismic performance of reinforced concrete core wall building with and without moment resisting frame “, 15th World Conference on Earthquake Engineering 2012.

14. JAVED, MOHAMMED, BASHIR ALAM, and SYED MOHAMMAD ALI. "SEISMIC RESISTANCE \& FAILURE MODES IN UNREINFORCED MASONRY SHEAR WALLS-A COMPARISON OF EXPERIMENTAL AND ANALYTICAL RESULTS." Research and Development (IJCSEIERD) 2.4 (2012): 5570.

15. Shadulla and K M, "Analysis of tube in tube structure with different size of inner tube", International journal of Technical Innovation in Modern Engineering \& Science, Vol. 4, Issue10, 2018, pp.7583.

\section{AUTHORS PROFILE}

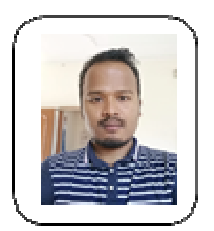

DiwakarChaudhary currently pursuing his M.E- structural Engineering from Chandigarh University (CU), Mohali, Punjab, India. He received his Bachelor's degree from Visvesvaraya Technological University (VTU), Karnataka, India. His area of research interests are Design, Analysis, Estimation and Costing.

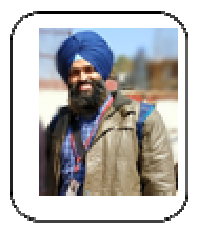

Gurpreet Singh Assistant Professor, Department of Civil Engineering, Chandigarh University (CU), Gharuan, Mohali, Punjab, India received M.E. - Structural Engineering from Thapar University, Patiala, India in 2014. Research Interest areas are Structural Engineering, Earthquake Engineering, Concrete, Composite Structures and Dynamic Analysis of Frames. 

